\title{
Late Quaternary lacustrine ostracods (Ostracoda, Crustacea) and charophytes (Charophyta, Charales) from the Puna Plateau, Argentina
}

\author{
Manuel R. Palacios-Fest ${ }^{1 *}$, Gabriela C. Cusminsky ${ }^{2}$ \& Michael M. McGlue ${ }^{3}$ \\ ${ }^{1}$ Terra Nostra Earth Sciences Research, LLC, PO Box 37195, Tucson, Arizona 85740-7195, USA \\ 2 INIBIOMA-CONICET and Centro Regional Universitario de Bariloche, Universidad Nacional de Comahue, Quintral \\ 12508400 San Carlos de Bariloche, Argentina \\ ${ }^{3}$ Department of Earth and Environmental Sciences, University of Kentucky, Lexington, KY 40506, USA \\ *Correspondence: mrpalacios@tnesr.com
}

\begin{abstract}
Relatively little is known about the recent palaeontological records of the high-altitude closed basin lakes of the Central Andes, but a great need exists to remedy this knowledge gap if microfossils are to be used to infer climatic and ecological transitions from lake sediment cores. Here, eight species of non-marine ostracods and two calcareous algae are recorded from modern sediments and late Quaternary strata from Laguna de los Pozuelos, Jujuy Province, northwestern Argentina. Four species, Limnocythere alexanderi, Limnocythere foresteri, Limnocythere lysandrosi and Limnocythere ruipunctifinalis, are described as new species. Limnocythere titicaca Lerner-Seggev, 1973 has only been recorded in Lake Titicaca prior to this study and this is the first time the species is recognized outside of Bolivia. The cypridoideans Ilyocypris ramirezi Cusminsky \& Whatley, 1996, Eucypris virgata Cusminsky \& Whatley, 1996 and Chlamydotheca pseudobrasiliensis Martens \& Behen 1994 are known species that are rare in the stratigraphic sequence in core LP06-6A. Also, the gyrogonites of two well-known species of Charophyta, Chara filiformis Hertzsch and Chara vulgaris Linnaeus, are occasionally present in the sediment from Laguna de los Pozuelos. The results provide a new vehicle for clarifying the Quaternary palaeohydrological history of the Pozuelos Basin, which is a RAMSAR wetland that is likely to be sensitive to global environmental change.
\end{abstract}

Keywords: Ostracoda; Charophyta; taxonomy; biostratigraphy; northwestern Argentina

Received 21 April 2015; accepted 19 August 2015

The main objective of this paper is to report on the ostracod and charophyte content in core LP06-6A, which was obtained from the centre of Laguna de los Pozuelos, Jujuy, northwestern Argentina (Noroeste Argentino; NOA) (McGlue et al. 2013). With a length of almost $4 \mathrm{~m}$, core LP06-6A shows a complex lithostratigraphy described in McGlue et al. (2013). The basal calibrated radiocarbon date from LP06-6A is c. $37.2 \mathrm{ka}$, which indicates that much of the late Pleistocene and Holocene is captured in the sequence. Due to its complexity, this study has been divided into the taxonomic analysis of the flora and fauna (this paper) and the palaeoecological reconstruction currently in preparation by the present authors. The taxonomic study includes the description of four new species of limnocytherids, a known limnocytherid, and three known cypridoideans, as well as two species of charophytes that occur periodically in the lake sediments.

\section{Study area}

The Pozuelos Basin is located in the NW corner of Jujuy Province (Argentina), at approximately $22^{\circ} \mathrm{S}$ latitude and $66^{\circ} \mathrm{W}$ longitude (Igarzábal 1978). It is a high altitude, elongate, piggyback structure with a NNE orientation (McGlue et al. 2012). The basin floor (c. $3663 \mathrm{~m}$ above sea-level (asl)) is flanked by mountains that reach more than $4000 \mathrm{~m}$ asl, and the spill point of this endorheic system is about $40 \mathrm{~m}$ above the modern playa-lake (Fig. 1).

Formed during the Oligocene, the origins of the Pozuelos Basin are tectonically complex, and the most recent deformation is associated with extensional normal faulting and volcanism (Cladouhos et al. 1994; Cohen et al. 2014). However, the marginal topography has been generated by thrust faults. Neogene ignimbrites occur along the eastern margin of the basin, whereas Cretaceous nonmarine sediments crop out to the south. The western basin margin is dominated by Ordovician siliciclastic and volcanic rocks. Miocene non-marine carbonates, evaporites and tuff (e.g. Cara Cara Formation; Cladouhos et al. 1994) are exposed along the eastern basin margin, potentially supplying hard water to the playa lake from the east.

The Puna region of NOA is extremely arid and relatively cold; monthly mean air temperatures range between $3^{\circ} \mathrm{C}$ and $13^{\circ} \mathrm{C}$ (Legates \&Willmott $1990 a, b$ ). Strongly seasonal precipitation is dominantly from eastern sources, with about $70 \%$ of rainfall occurring during the austral summer. The average precipitation is about $320 \mathrm{~mm} \mathrm{a}^{-1}$. The South American summer monsoon (SASM; Zhou \& Lau 1998) controls the climate and, as with most of the Puna plateau, the El Niño Southern Oscillation (ENSO) phenomenon and North Atlantic sea surface temperatures regulate patterns of modern precipitation over the Pozuelos Basin (Garreaud et al. 2009). Grasses, shrubs, succulents and macrophytes constitute the vegetation cover, characterizing a mixture of $\mathrm{C}_{3}$ and $\mathrm{C}_{4}$ plants that are distributed in the area following topographic and soil-moisture gradients (Bonaventura et al. 1995; McGlue et al. 2012, 2013).

The concentration of solutes is relatively high in extant Laguna de los Pozuelos (LP), with $\mathrm{Na}^{+}$and $\mathrm{Ca}^{2+}$ (553 $\mathrm{mgl}^{-1}$ and $129 \mathrm{mgl}^{-1}$, respectively) dominating the cation composition, and $\mathrm{Cl}^{-}$and $\mathrm{HCO}_{3}^{-}$are the most significant anions $\left(761 \mathrm{mgl}^{-1}\right.$ and $198 \mathrm{mgl}^{-1}$ ). Magnesium is present at a concentration of $30 \mathrm{mgl}^{-1}$, indicating a relatively low $\mathrm{Mg} / \mathrm{Ca}_{\text {water }}$. Playa waters are oxygen saturated, brackish (4 to $29 \mathrm{ppt}$ ), basic (mean $\mathrm{pH}$ of 8.7 ) and 

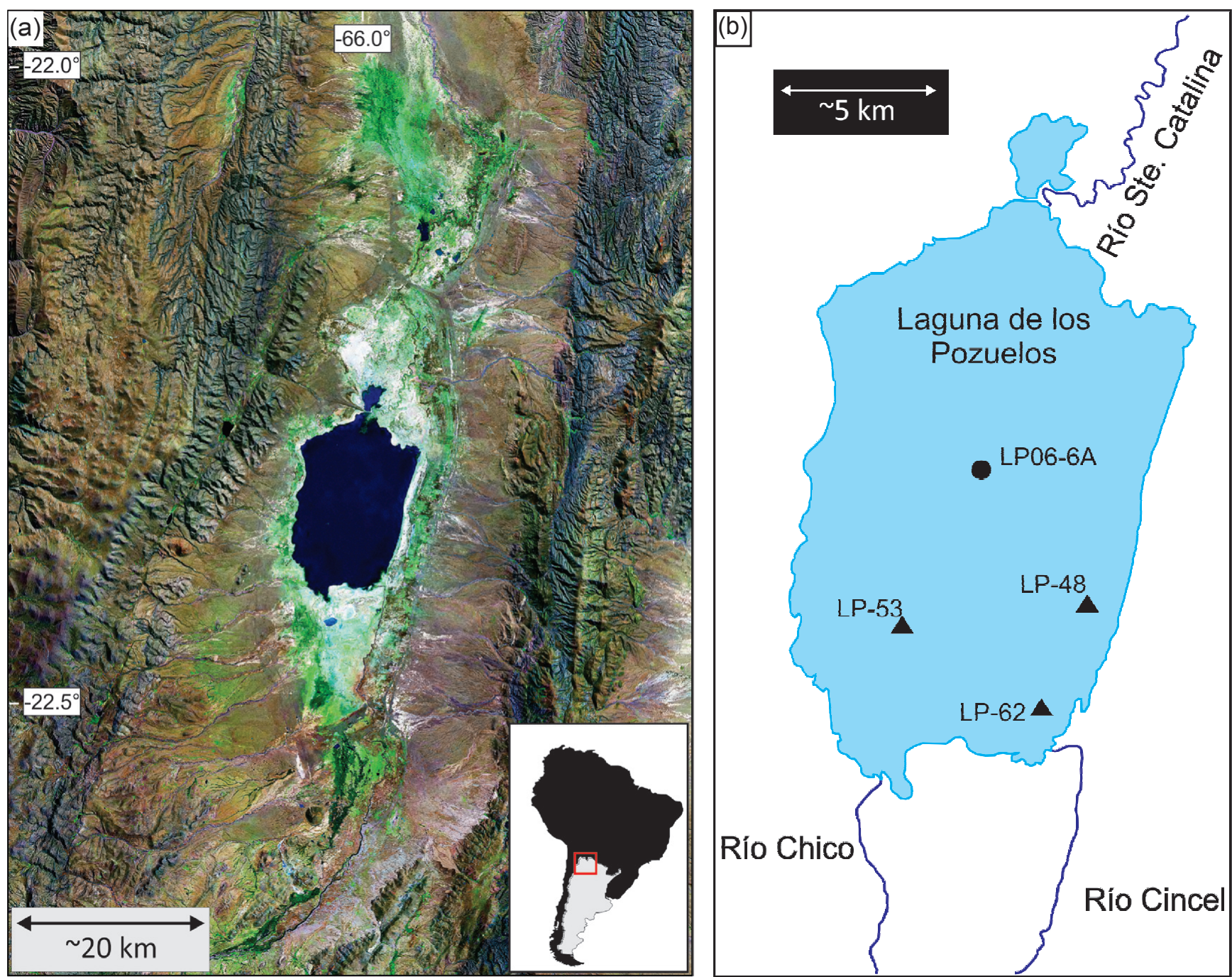

Fig. 1. (a) Satellite image of Laguna de los Pozuelos, Jujuy Province, Argentina (inset shows the position of the basin in South America); and (b) schematic map showing Laguna de los Pozuelos, major riverine inputs and the approximate location of core LP06-6A (filled circle) and three surface samples (filled triangles) discussed in this paper (modified from McGlue et al. 2013).

appear to be spatially homogeneous based on available measurements (McGlue et al. 2012). These patterns probably result from wind mixing of the shallow water column and a low groundwater table.

Laguna de los Pozuelos is a hydrologically closed basin that is sensitive to changes in effective precipitation (P-E; McGlue et al. 2012); hence, its surface area is subject to annual variations that may expand to about $135 \mathrm{~km}^{2}$ during years above average precipitation to a dry-playa as the lake desiccates during prolonged droughts (Mirande \& Tracanna 2009; McGlue et al. 2013). No evidence has yet been discovered that would suggest that LP water levels reached the basin spill point and overflowed in the late Quaternary. The basin floor is flat, favouring the lateral expansion of the playa-lake that, at maximum depth, does not exceed $1.5 \mathrm{~m}$. The available evidence indicates that LP is polymictic; weak southeasterly summer winds and stronger westerly winter winds prevent the lake from developing persistent stratification. Ground and surface waters feed the lake; the Ríos Cincel and Chico are largely permanent rivers and form axial deltas at the southern end of Laguna de los Pozuelos, whereas the Río Santa Catalina is an ephemeral drainage that forms a seasonally subaerial terminal splay complex at the opposite end of the lake (McGlue et al. 2012). Numerous small and ephemeral streams form alluvial fans along the lake's lateral margins (McGlue et al. 2012). At times, it is likely that the inflowing rivers may have ceased during extreme arid periods, but our core records are not spatially extensive enough to resolve if LP ever fully dried out.

\section{Material and methods}

Sediment core LP06-6A was collected from LP in 2006, using a gasoline-powered hammer coring device on loan from the Universidad Nacional de Jujuy. The core was retrieved from a central axial position in the playa-lake $\left(c .22 .333^{\circ} \mathrm{S}\right.$ latitude, c. $66.003^{\circ} \mathrm{W}$ longitude) during the dry season, when water levels had receded. A total of $372 \mathrm{~cm}$ of sediment was recovered in multiple drives from the site (McGlue et al. 2013). The core was sealed in the field and transported to the National Lacustrine Core Repository (Laccore) in Minneapolis, Minnesota (USA) for processing and analysis. Core top sediments from the 6A site were barren of ostracods, and core top sediments from other LP cores were likewise dominated by siliciclastic material and the absence of calcareous microfossils. Therefore, in order to assess the modern biota, several $(n=3)$ lake floor grab samples were processed from the southern end of Laguna de los Pozuelos, where standing water can be encountered more frequently due to the presence of inflowing rivers. The specific details of modern sediment sampling have been presented elsewhere (McGlue et al. 2012).

Thirty-seven samples from core LP06-6A were analysed for microfossils (ostracods and calcareous algae). The sample 
intervals are identified in centimetres below ground surface $(\mathrm{cm}$ bgs). Samples were prepared using routine procedures (Forester 1988) modified by Palacios-Fest (1994). In order to disaggregate the samples, they were air-dried, weighed and soaked in boiling water with $1 \mathrm{~g}$ of Alconox. Following the boiling Alconox bath, the samples were left to sit at room temperature for five days; each sample was vigorously stirred once per day. Using a set of three sieves, the samples were then washed under a gentle shower to separate the coarse $(>1 \mathrm{~mm})$, medium $(>106 \mu \mathrm{m})$ and fine $(>63 \mu \mathrm{m})$ sand-size fractions. The sand-size fraction consisted mostly of biogenic materials and some detrital particles; all samples were examined to identify fossil content and evidence of biological assemblages.

\section{Systematic palaeontology}

\section{The Ostracoda}

The ostracod species identified in this study are described based on hard-part carapace morphology and not on soft parts. Holotypes are deposited in the collections of the Micropaleontology Laboratory of Museo de la Plata (MLP), Argentina, under the prefix MLP-Mi 1948-1968, and are archived under the photographic catalogue numbers TNESR-Cat.-0001-0103 inclusive. A set of paratypes is kept at Terra Nostra Earth Sciences Research, LLC, whereas the specimens used for scanning electron microscopy (SEM images) are archived at the Laboratorio de Micropaleontología del Instituto de Ciencias del Mar y Limnologia, National Autonomous University of Mexico under the prefix ICMLO-2535-2560. All dimensions are given in millimetres; $\mathrm{RV}$, right valve; $\mathrm{LV}$, left valve; $\mathrm{C}$, articulate carapace; J, juvenile. The size conventions used in this study are as follows: $<0.40=$ very small, $0.40-0.50=$ small, $0.50-0.70=$ medium, $0.70-1.00=$ large, $>1.00=$ very large. The abbreviations used in this paper are as follows: EVRV, exterior view, right valve; IVRV, interior view, right valve; EVLV, exterior view, left valve; IVLV, interior view, left valve. The higher classification is based on Martens \& Savatenalinton (2011).

Class Ostracoda Latreille, 1806

Subclass Podocopa Muller, 1894

Order Podocopida Sars, 1866

Suborder Cypridocopina Baird, 1845

Superfamily Cypridoidea Baird, 1845

Family Ilyocyprididae Kaufmann, 1900

Subfamily Ilyocypridinae Kaufmann, 1900

Genus Ilyocypris Brady \& Norman, 1889

Type species. Ilyocypris gibba (Ramdohr, 1808)

Ilyocypris ramirezi Cusminsky \& Whatley, 1996

(Pl. 1, fig. 1)

1996 Ilyocypris ramirezi Cusminsky \& Whatley: pl. I, figs 11-14.

?1967 Ilyocypris gibba (Ramdohr, 1808); Ramírez: 21, pl. 2, figs 4-9.

1981 Ilyocypris gibba (Ramdohr, 1808); Zabert: pl. 1, fig. 4; pl. 2 , fig 8 .

1990 Ilyocypris gibba (Ramdohr, 1808); Bertels \& Martínez: pl. 1, fig. 16.

2002 Ilyocypris ramirezi Cusminsky \& Whatley; Schwalb et al.: pl. 1, fig. 12.

2005 Ilyocypris ramirezi Cusminsky \& Whatley; Cusminsky et al:: pl. 3, figs 6-8.

Material. One adult valve.
Brief description. A large species of Ilyocypris with subdued swellings and sulci in the antero-dorsal region. Sub-marginal spinose tubercles anteriorly and posteriorly and a regular reticulum of sub-rounded to sub-cribrose fossae.

Dimensions. Female RV, TNESR 0098: L 0.840 mm, H 0.420 mm; MLP-Mi 1949, LP06-6A:62, modern surface.

Occurrence. Ilyocypris ramirezi occurs only once in surface sediments in Laguna de los Pozuelos (LP06-62; cf. McGlue et al. 2012).

Distribution. The species was first reported from Los Juncos Lake, Estación Perito Moreno, Rio Negro Province, from sample 6, $100 \mathrm{~cm}$ from top of core; $41^{\circ} 03^{\prime} \mathrm{S}$ latitude, $71^{\circ} 0^{\prime} \mathrm{W}$ longitude

Remarks. As with Cusminsky \& Whatley's (1996) specimens, the single valve identified in this study is slightly smaller than I. gibba from Ramirez's (1967) study from Lago Monte, Buenos Aires, and Bertels and Martinez's (1990) investigation from Quaternary deposits in the south of Buenos Aires province. Cusminsky \& Whatley (1996) found this species in the beds of both Los Juncos Lake (samples 5, 6, 7) and La Salina Lake (sample 6) in northern Patagonia. Schwalb et al. (2002) and Cusminsky et al. (2005) found this species in running water and in ephemeral lakes, such as Laguna Cari-Laufquen. It also occurs in permanent lakes in northern Patagonia but inhabits predominantly streams and spring seeps (Cusminsky et al. 2005). D'Ambrosio et al. (2015) described the species soft parts for specimens recovered seasonally from a spring creek and the river delta in the Cuyo region, western Argentina. Its geographical range may be extended to Laguna de los Pozuelos, Jujuy, northern Argentina.

Family Cyprididae Baird, 1845

Subfamily Eucypridinae Bronshtein, 1947

Genus Eucypris Vávra, 1891

Type species. Monoculus virens, Jurine 1820.

Eucypris virgata Cusminsky \& Whatley, 1996

(Pl. 1, fig. 2)

1996 Eucypris virgata Cusminsky \& Whatley: pl. I, figs 17, 18; pl. II, figs $1-3$.

2002 Eucypris virgata Cusminsky \& Whatley; Schwalb et al.: pl. 1 , fig. 4.

2005 Eucypris virgata Cusminsky \& Whatley; Cusminsky et al.: pl. 2, figs $5-7$.

Material. One juvenile RV.

Brief description. Large species of Eucypris characterized by a rather narrowly rounded anterior margin and a very pointed posterior, virgate ribbing, marginal reticulation and pustule-like tubercles.

Dimensions. RV, TNESR 0099: L $0.640 \mathrm{~mm}, \mathrm{H} 0.320 \mathrm{~mm}$; MLP-Mi 1950, LP06-6A, 299.5-301.5 cm bgs.

Occurrence. Occurs once in core LP06-6A in Laguna de los Pozuelos (Core LP06 at c. 299.5-301.5 cm).

Distribution. This juvenile valve has the characteristic ornamentation of the species described by Cusminsky \& Whatley (1996) and it occurs especially in permanent ponds, lakes, springs, creeks and non-permanent aquatic environments of northern Patagonia (Cusminsky \& Whatley 1996; Schwalb et al. 2002; Cusminsky et al. 2005). Its occurrence in Laguna de los Pozuelos extends its presence to northern Argentina. 


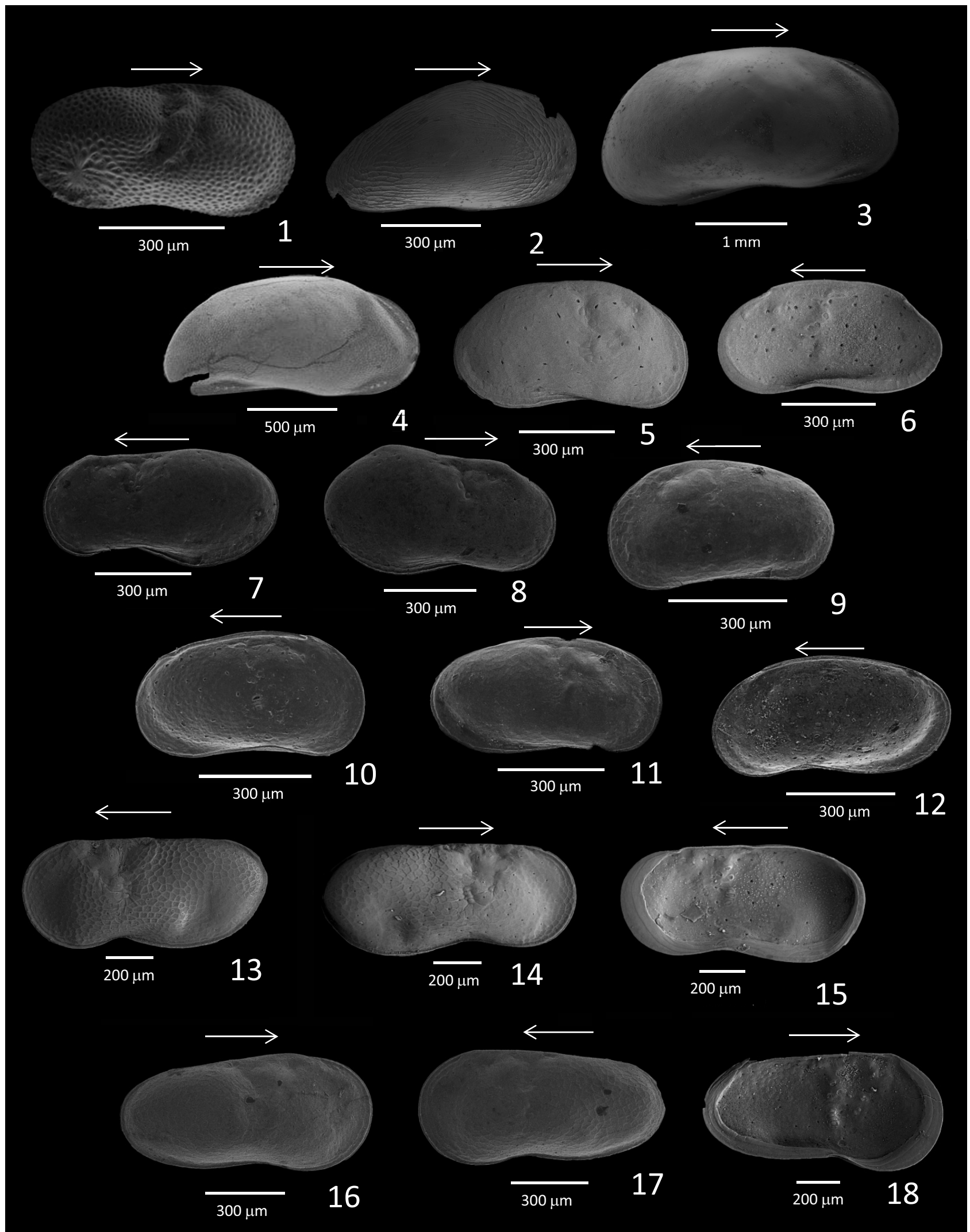

Explanation of Plate 1. fig. 1. Ilyocypris ramirezi Cusminsky \& Whatley, 1996; adult female, exterior view, right valve, MLP-Mi-1949. fig. 2. Eucypris virgata Cusminsky \& Whatley, 1996; juvenile exterior view, right valve, MLP-Mi- 1950. figs 3, 4. Chlamydotheca pseudobrasiliensis Martens, 1994: 3, pre-adult (A-1) exterior view, right valve, MLP-Mi-1951; 4, juvenile (A-3) exterior view, right valve, ICMLO-2535. figs 5-8. Limnocythere alexanderi n. sp.: 5, adult female, exterior view, right valve, paratype, ICMLO-2536; 6, adult female, interior view, right valve, paratype, ICMLO-2536; 7, adult male, exterior view, left valve, paratype, ICMLO-2537; 8, adult male, exterior view, right valve, paratype, ICMLO-2538. figs 912. Limnocythere foresteri $\mathrm{n}$. sp.: 9, adult female, exterior view, left valve, paratype, ICMLO-2539; 10, adult female, interior view, left valve, paratype, ICMLO-2539; 11, adult male, exterior view, right valve, paratype, ICMLO-2540; 12, adult male, interior view, right valve, paratype, ICMLO-2540. figs 13-18. Limnocythere lysandrosi $\mathrm{n}$. sp.: 13, adult male, exterior view, left valve, paratype, ICMLO-2541; 14, adult male, exterior view, right valve, paratype, ICMLO-2542; 15, adult male, interior view, right valve, paratype, ICMLO-2542; 16, adult female, exterior view, right valve, paratype, ICMLO-2543; 17, adult female, exterior view, left valve, paratype, ICMLO-2544; 18, adult female, interior view, left valve, paratype, ICMLO-2544. 
Remarks. This species is distinguished from E. sarsi Daday, 1902 [= E. fontana (Graf, 1931)] from the Recent of southern Patagonia in shape and size. The latter species has its highest point more posterior than the present species. Although Daday's illustrations are very poor, his material seems to have a similar type of ornament. The species differs from E. labyrinthica Cusminsky \& Whatley (1996) in its stronger ornamentation and its more elongate shape and pointed posterior. Although the adults of this species are very distinctive and demonstrate clear adult characteristics, especially with respect to the nature of the inner lamella, the juveniles are rather similar to those illustrated by De Deckker (1981) as juveniles of $E$. fontana (Graf). We interpret this single juvenile valve as a form of E. virgata described by Cusminsky \& Whatley (1996).

Subfamily Cypridinae Baird, 1845

Genus Chlamydotheca Saussure, 1858

Type species. Cypris (Chlamydotheca) azteca Saussure, 1858.

Chlamydotheca pseudobrasiliensis Martens \& Behen, 1994 (Pl. 1, figs 3, 4)

1949 Chlamydotheca brasiliensis Tressler: 72, fig. 13d-g. 1994 Chlamydotheca pseudobrasiliensis: Martens in Martens \& Behen: 9.

Material. 26 adults and juveniles (mostly fragmented).

Brief description. Large carapace with both valves similar in shape characterized by a moderately developed anterior flange. LV overlaps RV. Greatest height slightly anterior of centre in dorsal margin. Ocular region slightly indented. Anterior end more broadly rounded than posterior. Ventral margin slightly convex in the centre. Surface of valves smooth. Hyaline border and pore canals lacking. No males known.

Dimensions. Female (A-1) (SEM) EVRV, TNESR 0102: L $3.100 \mathrm{~mm}$, H $1.900 \mathrm{~mm}$; MLP-Mi 1951, LP06-6A, modern surface. Female (A-3) (SEM) EVRV, TNESR 0100: L 1.120 mm, H $0.560 \mathrm{~mm}$; ICMLO-2535, LP06-6A, 276.5-278.5 cm bgs.

Occurrence. Chlamydotheca pseudobrasiliensis occurs rarely in LP (core LP06-6A at depths of approximately $131 \mathrm{~cm}, 277.5 \mathrm{~cm}$, $299.8-323.5 \mathrm{~cm}, 347.5 \mathrm{~cm}$ and $361.5 \mathrm{~cm}$, as well as modern samples LP06-48 and LP06-53).

Distribution. Tressler (1949) reports the species in an artificial lake near Lavras, Ceará, Brazil in low numbers. Rare also in this study. Holotype, USNM No. 83012.

Remarks. The present material closely resembles Chlamydotheca pseudobrasiliensis Martens, 1994 as illustrated by Tressler (1949). The specimens differ in detail from those documented by Diebel \& Pietrzeniuk (1975), Calderoni et al. (1994), Tunoglu et al. (1995) and Zhencheng et al. (1999). Our specimens, however, are very fragmentary. One adult RV and several juvenile forms appear to form the scarce population in LP. The adult form is broken but larger than $3 \mathrm{~mm}$ in length and $2 \mathrm{~mm}$ high.

Superfamily Cytheroidea Baird, 1850

Family Limnocytheridae Klie, 1938

Subfamily Limnocytherinae Klie, 1938

Tribe Limnocytherini Klie, 1938

Genus Limnocythere Brady, 1968

Type species. Cythere inopinata Baird, 1843.

Limnocythere alexanderi $\mathrm{n} . \mathrm{sp}$.

(Pl. 1, figs 5-8; Fig. 3a, b)
Derivation of name. In honour of Alexander Qais, the senior author's third grandson.

Diagnosis. Subtrapezoidal carapace, dorsal margin straight. Welldefined cardinal angles, especially the anterodorsal. Ventral margin concave in the middle (oral incurvature). Surface weakly reticulate with fine muri and polygonal fossae. Large pore canals. Bisulcate, the anterior sulcus shallower than the posterior sulcus. Female and male well differentiated.

Holotype. Male right valve; MLP-Mi-1952; LP06-6A:276.5$278.5 \mathrm{~cm}$ bgs.

Paratypes. Both valves of male and female specimens; MLP-Mi-1953/1955; SEM image specimens: ICMLO-2536/2539; LP06-6A:276.5-278.5 cm bgs, LP06-6A:360.5-362.5 cm bgs.

Material. 274 adults and juveniles.

Type locality. Laguna de los Pozuelos (c. $22.333^{\circ} \mathrm{S}$ latitude, $c$. $66.003^{\circ} \mathrm{W}$ longitude).

Description. Female: Shape subquadrate in side view, greatest height anteriorly of middle, dorsal margin straight. Ventral margin concave in the middle; well-defined obtuse cardinal angles, especially the anterodorsal. Anterior margin broadly rounded; posterior margin rounded, slightly acuminate in the middle to rounded towards the postero-ventral margin. One or two nodes at the anterior and posterior ends of the hinge may or may not be present. Parallel to the dorsal margin is a sulcus intercepted by two longitudinal sulci. The anterior sulcus is shallower than the posterior sulcus. Surface of valves weakly reticulate, transparent or translucent with fine muri and polygonal fossae; normal pores common, large and cribrose type. Muscle scars as in genus. Inner lamella moderately narrow, slopping inward; inner margin and line of concrescence coincide throughout, subparallel to outer margin. Marginal pore canals few, simple, nearly straight. Hinge as in genus.

Male: Differs from females in being slightly more elongate with a club-shaped posterior half. Surface of valves reticulate. The hinge nodes may be more prominent and the posterior sulcus deeper than that of the female. Its greatest height lies in the posterior half of the valve. Other characteristics same as in female.

Dimensions. Male RV holotype, TNESR 0054: L $0.675 \mathrm{~mm}, \mathrm{H}$ $0.0350 \mathrm{~mm}$; MLP-Mi 1952, LP06-6A, $276.5-278.5 \mathrm{~cm}$ bgs. Male LV paratype, TNESR 0055: L 0.745 mm, H 0.410; MLP-Mi-1953, LP06-6A, 276.5-278.5 cm bgs. Female LV paratype, TNESR 0056: L $845 \mathrm{~mm}, \mathrm{H}$ 0.495; MLP-Mi 1954, LP06-6A, 360.5$362.5 \mathrm{~cm}$ bgs. Female RV paratype, TNESR 0057: L $0.650 \mathrm{~mm}, \mathrm{H}$ 0.370; MLP-Mi 1955, LP06-6A, 360.5-362.0 cm bgs. Male (SEM) EVRV, TNESR 0064: L $0.745 \mathrm{~mm}, \mathrm{H}$ 0.410; ICMLO-2536, LP06-6A, 276.5-278.5 cm bgs. Male (SEM) EVLV, TNESR 0066: L 0.710 mm, H $0.395 \mathrm{~mm}$; ICMLO-2537, LP06-6A, 276.5$278.5 \mathrm{~cm}$ bgs. Female (SEM) EVRV, TNESR 0068: L $0.682 \mathrm{~mm}$, H $0.364 \mathrm{~mm}$; ICMLO-2538, LP06-6A, 276.5-278.5 cm bgs. Female (SEM) IRVR, TNESR 0069: L $0.700 \mathrm{~mm}$, H $0.360 \mathrm{~mm}$; ICMLO-2539, LP06-6A, 276.5-278.5 cm bgs.

Occurrence. Limnocythere alexanderi $\mathrm{n}$. $\mathrm{sp}$. occurs throughout core LP06-6A in LP and is as abundant as L. lysandrosi $\mathrm{n}$. sp.

Distribution. This species is recorded for the first time from Quaternary sediments in LP. To the best of our knowledge the species has not been recovered anywhere else.

Remarks. Limnocythere alexanderi n. sp. resembles L. variabilis of Purper \& Pinto (1980); however, it clearly differs in the absence of a deep sulcus and the two diagnostic nodes in the anterior half of the valve that characterize $L$. variabilis. The specimens described here 


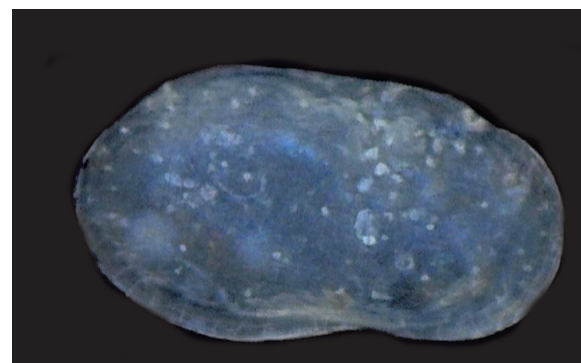

(a)
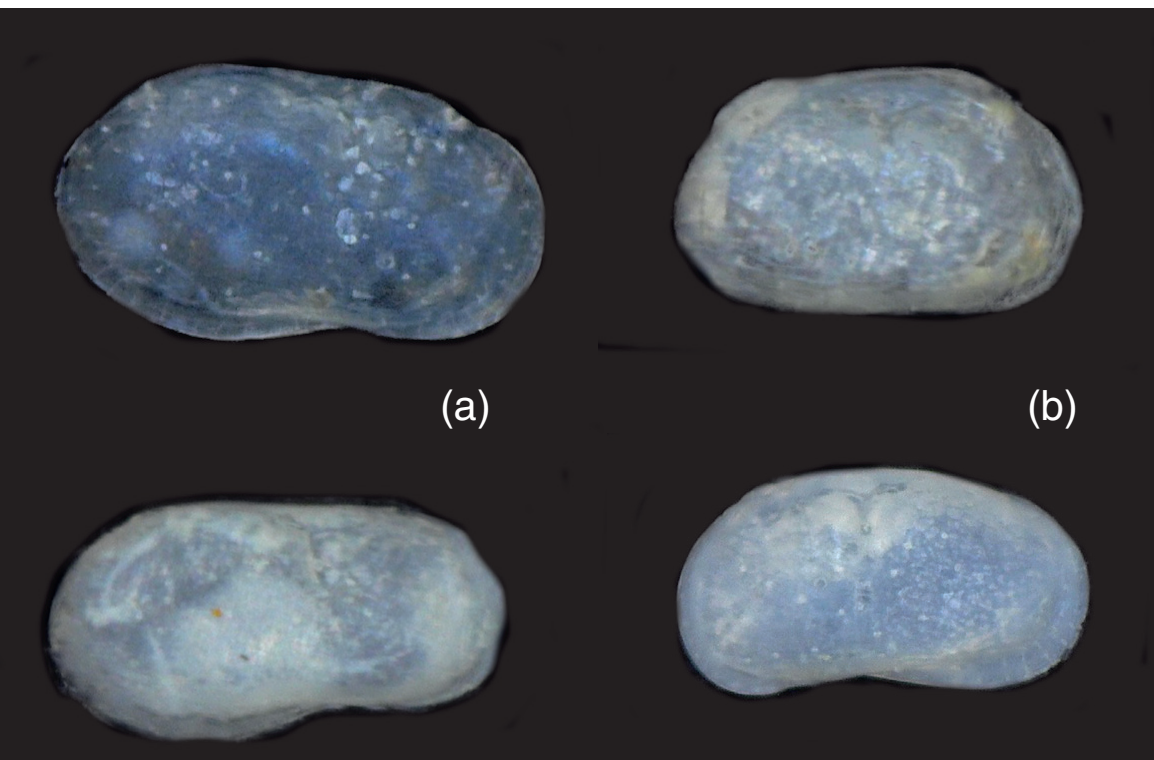

(c)

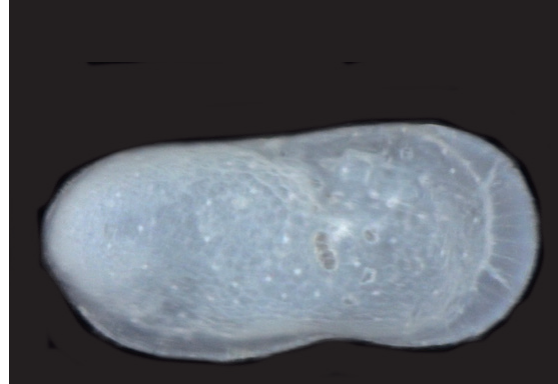

(e)

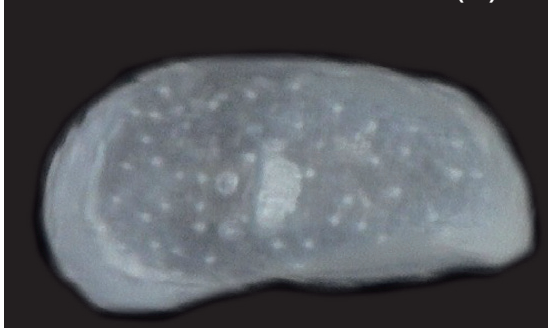

(g) (d)

(b)

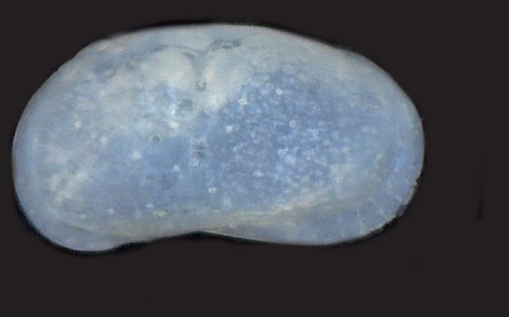

Fig. 2. (a) Holotype: male RV,

Limnocythere alexanderi $\mathrm{n} . \mathrm{sp} . ., 225 \mathrm{x}$. Dimensions: L $0.675 \mathrm{~mm} ; \mathrm{H} 0.350$. MLP-Mi 1952. (b) Paratype: female $\mathrm{LV}$, Limnocythere alexanderi $\mathrm{n} . \mathrm{sp}$. , 225x. Dimensions: L 0.845; H 0.495. MLP-Mi 1954. (c) Holotype: male $\mathrm{RV}$, Limnocythere foresteri $\mathrm{n}$. sp.., 225x. Dimensions: L 0.700; H 0.390 MLP-Mi 1956. (d) Paratype: female $\mathrm{LV}$, Limnocythere foresteri $\mathrm{n}$. sp.., 225x. Dimensions: L 0.590; H 0.290. MLP-Mi 1959. (e) Holotype: male $\mathrm{RV}$, Limnocythere lysandrosi $\mathrm{n}$. sp... 225x. Dimensions: L 1.420; H 0.465. MLP-Mi 1960. (f) Paratype: female $\mathrm{RV}$, Limnocythere lysandrosi $\mathrm{n} . \mathrm{sp}$. ., 225x. Dimensions: L 1.161; H 0.511. MLP-Mi 1963. (g) Holotype: male LV, Limnocythere ruipunctifinalis $\mathrm{n}$. sp.. Dimensions: L 0.560; H 0.279. MLPMi 1964. (h) Paratype: female RV, Limnocythere ruipunctifinalis $\mathrm{n}$. $\mathrm{sp}, 225 \mathrm{x}$. Dimensions: L 0.571; H 0.296. MLP-Mi 1966. show an acuminate posterior margin, lack of denticulations in the postero-ventral margin of left valve. It is significant that the males of $L$. alexanderi differ from those of $L$. variabilis in having the nodes at the extremes of the hinge, whereas the nodes of $L$. variabilis are both in front of the deep sulcus one above the other. Purper \& Pinto (1980) positively compare the female valves of $L$. variabilis to $L$. staplini Gutentag \& Benson, 1962, highlighting that the only difference is the slight sinuosity in the central dorsal margin. Dorsal margin in $L$. alexanderi is straight or slightly convex throughout. Therefore, we conclude that $L$. alexanderi is a new species.

\section{Limnocythere foresteri $\mathrm{n}$. sp}

$$
\text { (Pl. 1, figs 9-12; Fig. 3c, d) }
$$

Derivation of name. In honour of Dr Richard M. Forester for his invaluable contributions to micropalaeontology and ostracod research worldwide.

Diagnosis. A small form of Limnocythere characterized by a rectangular carapace; slightly convex dorsal margin. Pronounced antero-dorsal smooth tubercle; crystalline, smooth surface. Compressed anterior and ventro-dorsal margins giving them an acuminate appearance. Female and male well differentiated.

Holotype. Male right valve; MLP-Mi-1956; LP06-6A:232-234 cm bgs.

Paratypes. Both valves of male and female specimens; MLP-Mi-1957/1959; SEM image specimens: ICMLO-2540/2543; LP06-6A:59-61 cm bgs; LP06-6A:232-234 cm bgs, and LP06-6A: $360.5-362.5 \mathrm{~cm}$ bgs.

Material. 206 adults and juveniles.

Type locality. Laguna de los Pozuelos (c. $22.333^{\circ} \mathrm{S}$ latitude, c. $66.003^{\circ} \mathrm{W}$ longitude).

Description. Female: Shape subrectangular in side view; greater height anteriorly of middle; dorsal margin straight to slightly convex. Ventral margin somewhat concave toward the anterior end from the middle; anterior margin broadly rounded; posterior mar- 
gin narrowly rounded. Carapace elliptical in dorsal view; greatest width posteriorly; anterior end bluntly pointed; posterior end somewhat rounded. Surface of valves weakly reticulate, fine muri and polygonal fossae, transparent to translucent weak, anterodorsal sulcus; normal pores common, small, and simple type; however, several large pores appear to be cribrose. Muscle scars as in genus. Inner lamella moderately narrow, sloping inward; inner margin and line of concrescence coincide throughout, subparallel to outer margin. Marginal pore canals few, simple, nearly straight. Hinge as in genus.

Male: Males differ from females in being more elongate, in having a slightly sinuous shape, a more concave ventral margin, anterior and posterior margins broadly rounded. Its greatest height lies just behind the sulcus, and the antero-dorsal sulcus is deeper.

Dimensions. Male RV holotype, TNESR 0075: L $0.700 \mathrm{~mm}, \mathrm{H}$ 0.390 mm; MLP-Mi 1956, LP06-6A, 232-234 cm bgs. Male LV paratype, TNESR 0076: L $0.530 \mathrm{~mm}, \mathrm{H} 0.280 \mathrm{~mm}$; MLP-Mi 1957, LP06-6A, 232-234 cm bgs. Female RV paratype, TNESR 0077: L 0.530 mm, H 0.280 mm; MLP-Mi 1958, LP06-6A, 360.5$362.5 \mathrm{~cm}$ bgs. Female LV paratype, TNESR 0078: L $0.590 \mathrm{~mm}, \mathrm{H}$ $0.290 \mathrm{~mm}$; MLP-Mi 1959, LP06-6A, 232-234 cm bgs. Female (SEM) EVLV, TNESR 0082: L $0.540 \mathrm{~mm}$, H $0.290 \mathrm{~mm}$; ICMLO2540, LP06-6A, 59-61 cm bgs. Female (SEM) IVLV, TNESR 0083: L 0.540 mm, H 0.290; ICMLO-2541, LP06-6A, 59-61 cm bgs. Male (SEM) EVRV, TNESR 0084: L $0.630 \mathrm{~mm}, \mathrm{H} 0.330 \mathrm{~mm}$; ICMLO-2542, LP06-6A, 360.5-362.5 cm bgs. Male (SEM) IVRV, TNESR 0085: L $0.630 \mathrm{~mm}$, H $0.330 \mathrm{~mm}$; ICMLO-2543, 360.5$362.5 \mathrm{~cm}$ bgs.

Occurrence. Limnocythere foresteri $\mathrm{n}$. sp. occurs throughout core LP06-6A in LP but it is moderately abundant to rare. It reaches its maximum abundance in the modern playa-lake.

Distribution. This species is recorded for the first time from Quaternary sediments in LP. To the best of our knowledge the species has not been recovered anywhere else. To the best of our knowledge the species has not been recovered anywhere else.

Remarks. Male specimens of Limnocythere foresteri $\mathrm{n}$. sp. found in LP look like juvenile specimens of L. titicaca Lerner-Seggev, 1973. However, the well-developed valves of $L$. foresteri strongly suggest mature adults of a smaller species than $L$. titicaca. The females are more subquadrate than the females of L. titicaca and also much smaller. The clear dimorphism in small $L$. foresteri indicates these specimens are adults different from $L$. titicaca. Limnocythere foresteri is also similar to $L$. parascutariense Delorme, 1971; however, it differs in the surface reticulation which in $L$. foresteri is weak whereas $L$. parascutariense is heavily reticulated.

Limnocythere lysandrosi $\mathrm{n} . \mathrm{sp}$.

(Pl. 1, figs 13-18, Pl. 2, figs 1-3; Fig. 3e, f)

Derivation of name. In honour of Lysandros Emiliano, the senior author's first grandson.

Diagnosis. A very large form of Limnocythere. Dorsal margin straight, ventral margin strongly concave in the anterior third giving it a 'lobulated' aspect, especially at the postero-ventral margin where it reaches its greatest height. Surface strongly reticulate with shallow sulci (bisulcate). Female and male about the same size but female more subrectangular than male.

Holotype. Male right valve; MLP-Mi-1960; LP06-6A:59-61 cm bgs.
Paratypes. Both valves of male and female specimens; MLP-Mi-1961/1963; SEM image specimens: ICMLO-2544/2549; LP06-6A: 59-61 cm bgs, LP06-6A:241.5-243.5 cm bgs.

Material. 2231 adults and juveniles.

Type locality. Laguna de los Pozuelos (c. $22.333^{\circ} \mathrm{S}$ latitude, $c$. $66.003^{\circ} \mathrm{W}$ longitude).

Description. Female: Shape subrectangular to subtrapezoidal in side view; greatest height anteriorly of middle; dorsal margin straight, ventral margin very concave towards the anterior half; anterior margin broadly rounded, posterior margin forms an obtuse angle in the dorsal area that turns acute towards the ventral margin. Carapace elliptical in dorsal view; greatest width posteriorly; anterior and posterior margins rather rounded at about midheight. Surface of valves strongly reticulate, transparent to translucent; well-defined muri with thick margins and polygonal fossae, bisulcate, sulci shallow; normal pores few, medium-size, simple type, difficult to observe because of surface reticulation. Muscle scars as in genus. Inner lamella moderately broad, sloping inward; inner margin and line of concrescence coincide; anterior and posterior inner margins coincide throughout; anterior and posterior inner margins are semi-circular; marginal pore canals few, simple or bifurcate, and nearly straight; selvage weak. Hinge as in genus.

Male: Differs from female in being smaller and more elongate with greatest height posteriorly. The ventral margin is strongly concave towards the anterior half of the length. The anterior margin is broadly rounded and the posterior margin forms almost a straight angle at the end of the carapace.

Dimensions. Male RV holotype, TNESR 0001: L $1.420 \mathrm{~mm}, \mathrm{H}$ $0.465 \mathrm{~mm}$; MLP-Mi 1960, LP06-6A, 59-61 cm bgs. Male LV paratype, TNESR 0002: L $1.452 \mathrm{~mm}$, H $0.595 \mathrm{~mm}$; MLP-Mi 1961, LP06-6A, 59-61 cm bgs. Female LV paratype, TNESR 0003: L $1.466 \mathrm{~mm}$, H $0.520 \mathrm{~mm}$; MLP-Mi 1962, LP06-6A, 59-61 cm bgs. Female RV paratype, TNESR 0004: L $1.161 \mathrm{~mm}, \mathrm{H} 0.511 \mathrm{~mm}$; MLP-Mi 1963, LP06-6A, 59-61 cm bgs. Male (SEM) EVRV, TNESR 0009: L $1.171 \mathrm{~mm}, \mathrm{H} 0.651 \mathrm{~mm}$; ICMLO-2544, LP06-6A, 241.5-243.5 cm bgs. Male (SEM) IVRV, TNESR 0010: L $1.171 \mathrm{~mm}, \mathrm{H}$ 0.651; ICMLO-2545, LP06-6A, 241.5-243.5 cm bgs. Male (SEM) EVLV, TNESR 0011: L $1.153 \mathrm{~mm}, \mathrm{H} 0.446 \mathrm{~mm}$; ICMLO-2546, LP06-6A, 241.5-243.5 cm bgs. Female (SEM) IVLV, TNESR 0012: L $0.986 \mathrm{~mm}, \mathrm{H} 0.482 \mathrm{~mm}$; ICMLO-2547, 241.5-243.5 cm bgs. Female (SEM) EVRV, TNESR 0013: L $0.954 \mathrm{~mm}, \mathrm{H} 0.449 \mathrm{~mm}$; ICMLO-2548, LP06-6A, 241.5-243.5 cm bgs. Female (SEM) EVLV, TNESR 0014: L $0.980 \mathrm{~mm}, \mathrm{H}$ $0.468 \mathrm{~mm}$; ICMLO-2549, LP06-6A, 241.5-243.5 cm bgs.

Occurrence. Limnocythere lysandrosi $\mathrm{n}$. sp. occurs throughout core LP06-6A in LP. It is the most common species in the core.

Distribution. This species is recorded for the first time from Quaternary sediments in LP. To the best of our knowledge the species has not been recovered anywhere else.

Remarks. Specimens of Limnocythere lysandrosi $\mathrm{n}$. sp. found in LP appear similar to L. jobimi of Purper \& Pinto (1980). The individuals described here differ in the larger size, the more acuminate and truncated posterior margin of the males, the more delicate ornamentation, and the weaker sulci in both females and males.

Limnocythere ruipunctifinalis $\mathrm{n}$. $\mathrm{sp}$. (Pl. 2, figs 4-7; Fig. 3g, h) 


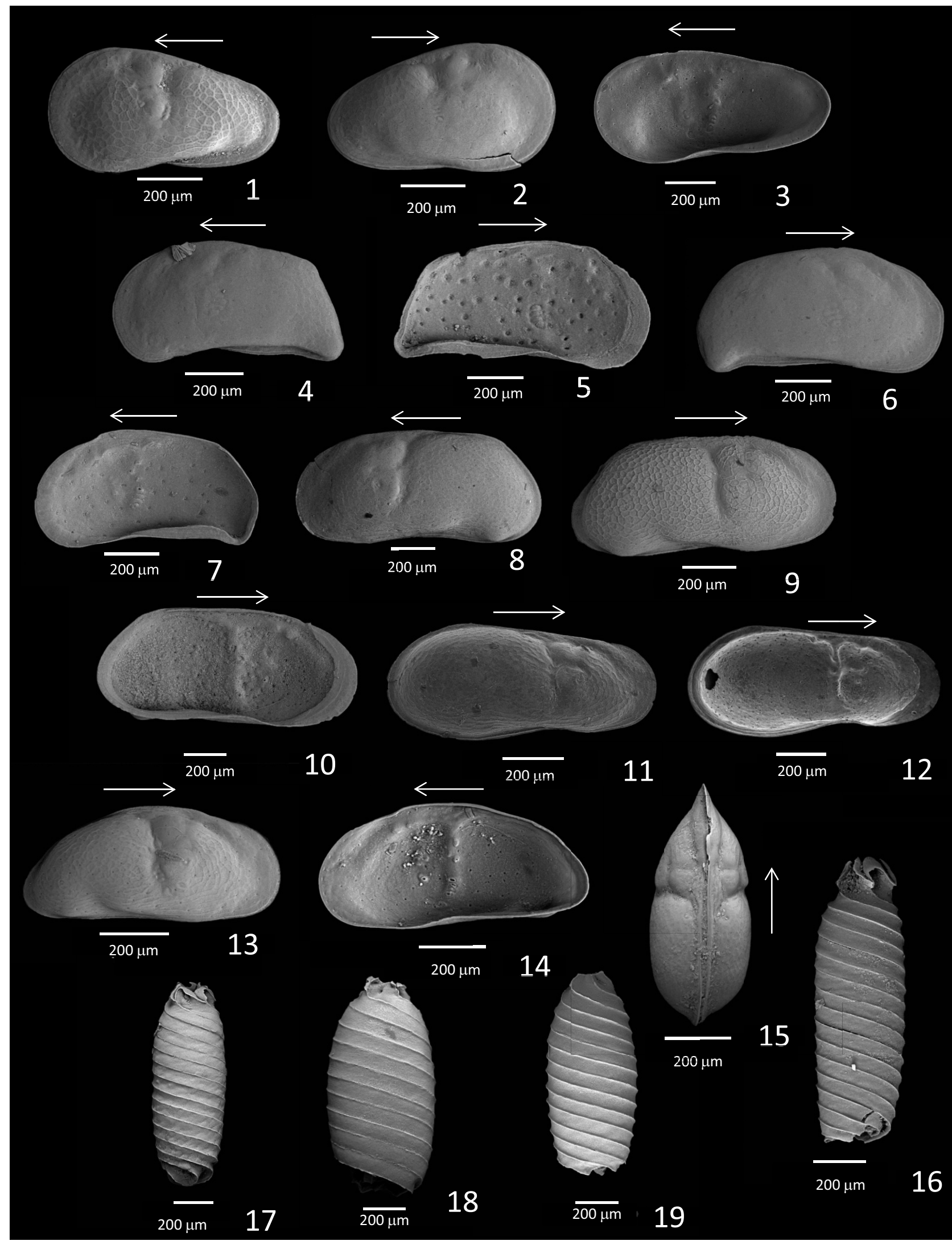

Explanation of Plate 2. figs 1-3. Limnocythere lysandrosi n. sp.: 1, juvenile, exterior view, left valve, paratype, ICMLO-2545; 2, juvenile, exterior view, right valve, paratype, ICMLO-2546; 3, juvenile, interior view, right valve, paratype, ICMLO-2547. figs 4-7. Limnocythere ruipunctifinalis $\mathrm{n}$. sp.: 4, adult male, exterior view, left valve, paratype, ICMLO-2548; 5, adult male, interior view, left valve, paratype, ICMLO-2548; 6, adult female, exterior view, right valve, paratype, ICMLO-2549; 7, adult female, interior view, right valve, paratype, ICMLO-2549. figs 8-15. Limnocythere titicaca LernerSeggev, 1973: 8, adult female, exterior view, left valve, ICMLO-2550; 9, adult female, exterior view, right valve, ICMLO-2551; 10, adult female, interior view, left valve, ICMLO-2550; 11, adult male, exterior view, right valve, ICMLO-2552; 12, adult male, interior view, left valve, ICMLO-2552; 13, juvenile, exterior view, right valve, ICMLO-2553; 14, juvenile, interior view, right valve, ICMLO-2554; 15, juvenile, dorsal view, ICMLO-2555. figs 16, 17. Chara filiformis Hertzsch, 2007, gyrogonite, lateral view: 16, MLP-Mi-1972; 17, ICMLO-2556. figs 18, 19. Chara vulgaris Linnaeus, 1753, gyrogonite, lateral view: 18, MLP-Mi-1973; 19, ICMLO-2557. 
Derivation of name. A combination derived from the senior author's second grandson, Rui Ricardo, and the species most characteristic feature, its posteroventral hook.

Diagnosis. A small species of Limnocythere characterized by a pointed hook at the postero-ventral margin. Posterior margin truncated obliquely. Dimorphism is difficult to recognize.

Holotype. Male left valve; MLP-Mi-1964; LP06-6A:59-61 cm bgs.

Paratypes. Both valves of male and female specimens; MLP-Mi-1965/1967; SEM image specimens: ICMLO-2550/2553; LP06-6A:59-61 cm bgs. LP06-6A:232-234 cm bgs.

Material. 842 adults and juveniles.

Type locality. Laguna de los Pozuelos (c. $22.333^{\circ} \mathrm{S}$ latitude, $c$. $66.003^{\circ} \mathrm{W}$ longitude).

Description. Female: Shape subrectangular in side view; greatest height anteriorly of middle; dorsal margin slightly convex, ventral margin concave, anterior margin broadly rounded, posterior margin obliquely truncated towards the ventral margin with slight subventral acumination, giving the margin a downturned appearance. Carapace elliptical in dorsal view; greatest width posteriorly; anterior end bluntly pointed but posterior end slightly bulbose. Surface of valves smooth, transparent to translucent; bisulcate, sulci shallow; normal pores common, medium to large simple type, clearly seen on the translucent surface. Muscle scars as in genus. Inner lamella moderately narrow, sloping inward; inner margin and line of concrescence coincide in ventral margin; anterior inner margin is semi-circular; whereas posterior inner margin is angular, selvage weak; inner list marked specially in the postero-ventral margin. Marginal pore canals few, simple and nearly straight. Hinge as in genus.

Male: The dorsal margin of males is straighter than females. The carapace of male differs from female in being subtrapezoidal and more elongate. Female's height slightly greater.

Dimensions. Male LV holotype, TNESR 0015: L $0.560 \mathrm{~mm}, \mathrm{H}$ $0.279 \mathrm{~mm}$; MLP-Mi 1964, LP06-6A, 59-61 cm bgs. Male RV paratype, TNESR 0016: L $0.600 \mathrm{~mm}$, H $0.595 \mathrm{~mm}$; MLP-Mi 1965, LP06-6A, 59-61 cm bgs. Female RV paratype, TNESR 0017: L $0.571 \mathrm{~mm}$, H $0.296 \mathrm{~mm}$; MLP-Mi 1966, LP06-6A, 59$61 \mathrm{~cm}$ bgs. Female LV paratype, TNESR 0018: L $0.579 \mathrm{~mm}, \mathrm{H}$ $0.300 \mathrm{~mm}$; MLP-Mi 1967, LP06-6A, 59-61 cm bgs. Male (SEM) EVRV, TNESR 0019: L $0.683 \mathrm{~mm}, \mathrm{H} 0.350 \mathrm{~mm}$; ICMLO-2550, LP06-6A, 232-234 cm bgs. Male (SEM) IVRV, TNESR 0020: L $0.725 \mathrm{~mm}$, H 0.346; ICMLO-2551, LP06-6A, 232-234 cm bgs. Female (SEM) EVLV, TNESR 0021: L $0.677 \mathrm{~mm}, \mathrm{H} 0.308 \mathrm{~mm}$; ICMLO-2552, LP06-6A, 232-234 cm bgs. Female (SEM) IVLV, TNESR 0022: L $0.683 \mathrm{~mm}, \mathrm{H} 0.350 \mathrm{~mm}$; ICMLO-2553, 232$234 \mathrm{~cm}$ bgs.

Occurrence. Limnocythere ruipunctifinalis $\mathrm{n}$. sp. occurs throughout core LP06-6A in LP; it is relatively abundant.

Distribution. This species is recorded for the first time from Quaternary sediments in LP. To the best of our knowledge the species has not been recovered anywhere else.

Remarks. Limnocythere ruipunctifinalis n. sp. found in LP appears similar to specimens of Limnocythere sp. figured by Cusminsky et al. (2005); the latter, however, presents a strongly reticulate surface, whereas L. ruipunctifinalis does not. Cusminsky et al. (2005) do not report males, as observed in LP. Limnocythere sp. of Cusminsky et al. (2005) occurs in Lago Cardiel, Province of Santa Cruz, southern Patagonia, an ephemeral, brackish-water body apparently similar to LP where L. ruipunctifinalis thrives. While Lago Cardiel has a $\mathrm{pH}$ of 9.11, a high concentration of sodium bicarbonate $\left(>1046 \mathrm{mgl}^{-1}\right)$, chloride $\left(>335 \mathrm{mgl}^{-1}\right)$ and sulphate (>906 $\mathrm{mgl}^{-1}$ ) (Cusminsky et al. 2005), average values for LP appear to be lower (mean $\mathrm{pH} 8.7$, sodium bicarbonate concentration of $283 \mathrm{mgl}^{-1}$ ). The difference in water chemistry preferences suggests they are two different species or at least that under sulphate-rich conditions the species is parthenogenetic.

\section{Limnocythere titicaca Lerner-Seggev, 1973}

$$
\text { (Pl. 2, figs 8-15) }
$$

1973 Limnocythere titicaca Lerner-Seggev: text-figs 2, 3, pl. 1. 1998 Limnocythere titicaca Lerner-Seggev, 1973; Mourguiart \& Corrège: pl. 2, fig. L.

Material. 1394 adults and juveniles.

Brief description. A large species of the genus Limnocythere. Female valves subtrapezoidal in lateral view, posterodorsal margin truncate, and heavily reticulate surface. Maximum height slightly anterior of middle. Male trapezoidal in lateral view, dorsal margin straight, posterior end broadly rounded, and weakly reticulate surface. Maximum height posterior of middle.

Dimensions. Female RV, TNESR 0042: L 0.840 mm, H 0.395 mm; MLP-Mi 1968, LP06-6A, 276.5-278.5 cm bgs. Female LV, TNESR 0045: L 0.900 mm, H 0.400 mm; MLP-Mi 1969, LP06-6A, 276.5$278.5 \mathrm{~cm}$ bgs. Male RV, TNESR 0064: L $0.980 \mathrm{~mm}, \mathrm{H} 0.485 \mathrm{~mm}$; MLP-Mi 1970, LP06-6A, 276.5-278.5 cm bgs. Male LV, TNESR 0065: L 0.960 mm, H 0.430 mm; MLP-Mi 1971, LP06-6A, 276.5$278.5 \mathrm{~cm}$ bgs. Female (SEM) EVRV, TNESR 0050: L 0.815 mm, H $0.360 \mathrm{~mm}$; ICMLO-2554, LP06-6A, 276.5-278.5 cm bgs. Female (SEM) EVLV, TNESR 0052: L 0.906 mm, H 0.413; ICMLO-2555, LP06-6A, 276.5-278.5 cm bgs. Female (SEM) IVLV, TNESR 0053: L 0.812 mm, H 0.365 mm; ICMLO-2556, LP06-6A, 276.5$278.5 \mathrm{~cm}$ bgs. Male (SEM) EVRV, TNESR 0071: L $1.050 \mathrm{~mm}, \mathrm{H}$ $0.510 \mathrm{~mm}$; ICMLO-2557, 360.5-362.5 cm bgs. Male (SEM) IVRV, TNESR 0072: L $1.050 \mathrm{~mm}, \mathrm{H} 0.510 \mathrm{~mm}$; ICMLO-2558, LP06-6A, $360.5-362.5 \mathrm{~cm}$ bgs.

Occurrence. Limnocythere titicaca occurs in the lower portion of core LP06-6A (abundant from $c .131-361.5 \mathrm{~cm}$ ) in LP and in modern surface samples. It is scarce in the upper part of the stratigraphic column.

Distribution. This species was first recorded from Quaternary sediments in Lake Titicaca, Bolivia (Lerner-Seggev 1973; Mourguiart \& Corrége 1998). Our specimens were recovered from Quaternary sediments in LP (McGlue et al. 2013).

Remarks. The valves from LP have a well-defined reticulation. They appear similar to Whatley \& Cholich's (1974) types of $L$. multiperforata. The specimens described here differ from L. multiperforata in the large size, the more acuminate posterior margin and the absence of pore canal clusters and reticulate surface. Juveniles are subtrapezoidal in side view with a sharply acuminate postero-dorsal margin.

\section{The Charophyta}

Calcareous algae are represented by the gyrogonites of two species showing a relative variability, as documented in the next section.

Class Charophyceae Smith, 1938

Order Charales Lindley, 1836

Family Characeae Agardh, 1824

Genus Chara Linnaeus, 1753 
Type species. Chara vulgaris Linnaeus, 1753.

Chara filiformis Hertzsch, 2007

(P1. 2, figs 16-17)

2007 Chara filiformis Hertzsch in Zviedre: 142.

Material. 45 gyrogonites.

Description. The oogonia of Chara filiformis are thin and elongated, solitary or geminate. Their height is greater than $0.750 \mathrm{~mm}$, width $0.300-0.400 \mathrm{~mm}$. Chara filiformis is characterized by $12-15$ convolutions (Wood 1959).

Dimensions. Dimensions of specimens are given as largest polar axis (LPA) and largest equatorial diameter (LED): Gyrogonite, TNESR 0090: LPA $0.900 \mathrm{~mm}$, LED $0.400 \mathrm{~mm}$; MLP-Mi 1972, LP06-6A, 276.5-278.5 cm bgs. Gyrogonite (SEM), TNESR 0093: LPA $0.900 \mathrm{~mm}$, LED $0.280 \mathrm{~mm}$; ICMLO-2559, LP06-6A, 276.5$278.5 \mathrm{~cm}$ bgs.

Occurrence. Chara vulgaris occurs in the lower portion of core LP06-6A and very rarely in the modern sediment samples from LP.

Remarks. Chara vulgaris is a common form frequently associated with $C$. filiformis. The few specimens identified in this study appear to correspond to Wood's (1959) diagnosis according to the following dimensions. Our gyrogonites range in size from 0.700 $0.900 \mathrm{~mm}$ in length (LPA median $=0.860 \mathrm{~mm}$ ) and 0.280 $0.400 \mathrm{~mm}$ in width (LED; median $=0.299 \mathrm{~mm}$ ). Isopolarity index averaged 277 (225-320); circumvolutions ranged from 12 to 15 (median $=13)$. Other characteristics as discussed by Wood (1959).

Modern ecology and palaeobiogeography. Chara filiformis shares the same type of environments identified for $C$. vulgaris. The species lives in alkaline waters with a $\mathrm{pH}$ between 7.5 and 10.5, it prefers high $\mathrm{pH}(9.5-10.5)$, Ca-rich, lotic or lentic waters; occasionally in spring seeps. It is intolerant of high nutrient conditions. The species thrives in permanent or ephemeral aquatic systems preferably during the late spring-summer, but may occur year-round. With a wide temperature range $\left(5-25^{\circ} \mathrm{C}\right)$ its optimal temperature is $17-22^{\circ} \mathrm{C}$. No records of $C$. filiformis, however, are available from South America. The specimens here identified may well be $C$. vulgaris var. kirghisorum forma filiformis.

Chara vulgaris Linnaeus, 1753 (Pl. 2, figs 18-19)

1967 Chara vulgaris Linnaeus, 1753; Wood: 12-13, figs 1-9.

Material. 7 gyrogonites.

Description. The oogonia of Chara vulgaris are highly polymorphic, solitary or geminate. They range in height from 0.525 to $0.800 \mathrm{~mm}$, width $0.335-0.525 \mathrm{~mm}$. Chara vulgaris is characterized by 13-16 convolutions (Wood 1959).

Dimensions. Gyrogonite, TNESR 0100: LPA $0.750 \mathrm{~mm}$, LED $0.400 \mathrm{~mm}$; MLP-Mi 1973, LP06-6A, $117.5-119.5 \mathrm{~cm}$ bgs. Gyrogonite (SEM), TNESR 0101: LPA $0.550 \mathrm{~mm}$, LED $0.430 \mathrm{~mm}$; ICMLO-2560, LP06-6A, 241.5-243.5 cm bgs.

Occurrence. Chara vulgaris occurs in the lower portion of core LP06-6A in LP (LP06-6A c. $242.5-254.5 \mathrm{~cm}$ and at $361.5 \mathrm{~cm}$ ).

Remarks. Chara vulgaris is a common form frequently associated with $C$. filiformis. The few specimens identified in this study appear to correspond to Wood's $(1959,1967)$ diagnosis accordingly to the following dimensions. Our gyrogonites range in size from 0.550 $0.750 \mathrm{~mm}$ in length $(\mathrm{LPA}$, median $=0.720 \mathrm{~mm}$ ) and $0.400-0.550 \mathrm{~mm}$ in width (LED; median $=0.430 \mathrm{~mm})$. Isopolarity index averaged 175 (128-200); circumvolutions ranged from 13 to 16 (median $=15)$. Other characteristics are discussed in Wood (1967).

Modern ecology and palaeobiogeography. The species lives in alkaline waters with a $\mathrm{pH}$ between 7.5 and 10.5, it prefers high $\mathrm{pH}$ (9.5-10.5), Ca-rich, lotic or lentic waters; occasionally in spring seeps. It is intolerant of high nutrient conditions. The species thrives in permanent or ephemeral aquatic systems preferably during the late spring-summer, but may occur year-round. With a wide temperature range $\left(5-25^{\circ} \mathrm{C}\right)$, its optimal temperature is 17 $22^{\circ} \mathrm{C}$. Currently, the species has been identified living in hypo- to oligo-saline lakes (salinity $0-5000 \mathrm{mg}^{-1}$ total dissolved solids; TDS) with a wide ionic composition at water depths not greater than $2 \mathrm{~m}$ (Romanov \& Barinova 2012). The genus is known to prefer littoral conditions. In Argentina Chara vulgaris has been recorded in Lago Pellegrini, Embalse E. R. Mexía in the provinces of Río Negro and Neuquén (García 1994).

\section{Discussion}

The stratigraphic and palaeoecological distribution of the species described in this paper will be discussed in detail in a future work by McGlue et al. The distribution of the Ostracoda and Charophyta in core LP06-6A are summarized here.

Figure 3 shows the relative stratigraphic distribution and abundance of ostracods and calcareous algae recovered from LP06-6A (McGlue et al. 2013). A total of eight ostracod and two calcareous algae species occur in LP. Diversity per sample ranges between two and eight species. From bottom to top, ostracods slowly increase in abundance to an abrupt decrease at about $225 \mathrm{~cm}$ bgs, then gradually the group re-establishes in the stratigraphic column reaching another maximum peak between about $80 \mathrm{~cm}$ bgs and $45 \mathrm{~cm}$ bgs. Calcareous algae followed a similar pattern, being more abundant in the lower portion of the core (below $225 \mathrm{~cm}$ bgs) than in its upper part. Two limnocytherids are the most common and abundant throughout the record, $L$. lysandrosi and $L$. ruipunctifinalis, closely followed by $L$. alexanderi, $L$. foresteri and $L$. titicaca. Amongst the cypridoideans, $C$. pseudobrasiliensis occurs more frequently near the base of the core but very seldom in its upper portion, whereas I. ramirezi occurs only twice at about $300 \mathrm{~cm}$ bgs and the modern playa-lake. A juvenile form of E. virgata (A-2) is recorded around $300 \mathrm{~cm} \mathrm{bgs}$ at the only time when all species are present. The Characea, C. filiformis and C. vulgaris, occur more randomly in the stratigraphic column, with the former being more common and abundant than the latter.

Limnocythere lysandrosi appears to be the most tolerant of a variety of ecological conditions, as it occurs during the most extreme environments recorded in LP, as well as during milder settings. Similarly, L. ruipunctifinalis is present throughout most of core LP06-6A, although in lower concentrations than L. lysandrosi, thus sharing with this species an apparent tolerance of a high range of salinity.

Limnocythere alexanderi is more abundant in the lower portion of the core (below $225 \mathrm{~cm} \mathrm{bgs}$ ), decreasing and sometimes disappearing from the record in the upper portion. Above $225 \mathrm{~cm}$ bgs, $L$. alexanderi is characterized by low concentrations, implying the potential for some environmental restrictions. With respect to the other limnocytherids, L. foresteri is the less abundant, yet relatively common throughout the stratigraphic column. With the exception of the modern samples, the species represents less than $30 \%$ of the total population and it occasionally disappears from the record altogether. Calcareous algae, particularly C. filiformis, are more abundant at intervals where $L$. alexanderi is also more 


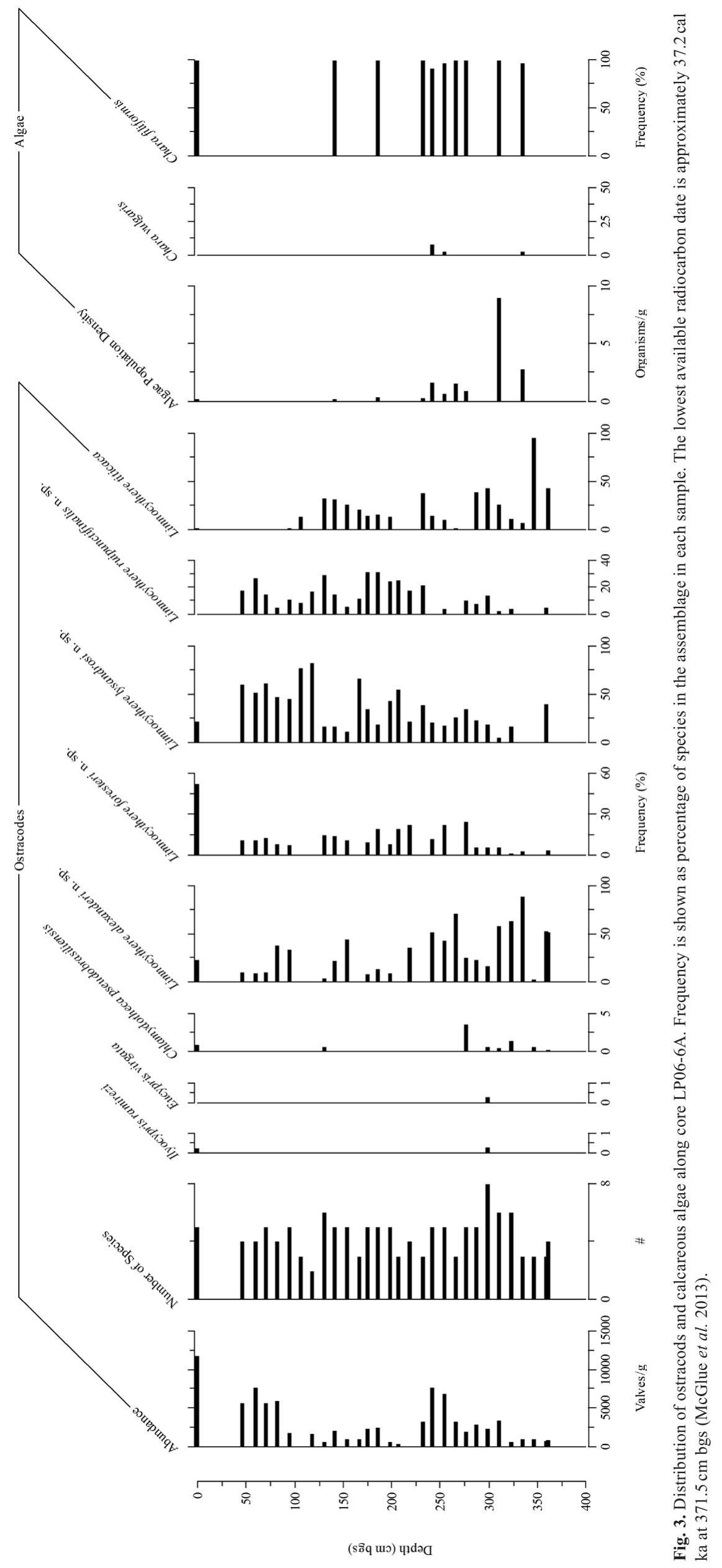


abundant; however, C. filiformis does not seem to be limited to coexisting with $L$. alexanderi. By contrast, $C$. vulgaris is extremely rare in the record but does not show a specific association with any ostracod species.

In spite of being fairly common, L. titicaca is the most vulnerable species to environmental change, as shown by the stratigraphic record and its distribution patterns. Dominant at the base of the core record where stratigraphic data indicate a permanent lake setting (McGlue et al. 2013), the species decreases in abundance and remains in low concentrations throughout two-thirds of the core. Limnocythere titicaca is last observed to occur in sediments horizons at approximately $100 \mathrm{~cm}$ bgs. No modern specimens of this ostracod are identified in LP. The species is associated with the three cypridoideans present in the basin, as well as all of the limnocytherids, implying atenuate salinity between 350 and $225 \mathrm{~cm}$ bgs. Fluctuations in simple species diversity throughout core LP06-6A seem to be in response to changes in $\mathrm{pH}$ and salinity, as well as desiccation of the basin, which is much more drastically in evidence above $40 \mathrm{~cm}$ bgs.

The biological record identified in LP includes a moderately diverse ostracod fauna but poorly diverse algal flora that fluctuate from relatively poor (22 specimens/sample) to very abundant ( $>450$ specimens/sample), implying that the lake experienced periodic events of flooding and desiccation that, in consequence, affected the history of salinization of the basin. With few modern records of the species present in the core LP06-6A and three surface samples, we can only infer the possible trends in salinity through time. The faunal assemblage and periodic occurrence of calcareous algae, in concert with stratigraphic and geochemical data from other sediment cores, allow us to interpret that LP evolved from a relatively freshwater lake to saline lake and a wetland during the past $37.2 \mathrm{ka}$ (McGlue et al. 2013). Calcareous algae suggest flowing waters at the time these organisms occurred in the lake. Like ostracods, the presence of charophytes indicates a variable environment ranging from oligohaline to mesohaline, which, as the group disappears, turns hypersaline.

It is likely that, at times, the inflowing rivers may have ceased during extreme arid periods, but our core records are not spatially extensive enough to resolve if LP ever fully dried out. If some deeper parts of the basin retained isolated, permanent water bodies, then this is potentially very interesting in terms of the development of individual ostracod lineages and the changes when the lake refilled and these water bodies were reunited.

\section{Conclusions}

LP shows a rich and diverse biological record, both in the modern lake and the Quaternary record, which will permit us to reconstruct a high resolution environmental history in response to episodes of lake expansion and contraction of this piggyback basin in northwestern Argentina. The analysis of a core and three surface samples resulted in the identification of four new ostracod species and new records of previously described species and calcareous algae that will contribute to our understanding of Andean lakes. Future additional research in NOA is required to validate the extent of endemism in the Pozuelos Basin.

\section{Acknowledgements and Funding}

The authors are grateful to Ricardo Pinto and David J. Horne for their editorial reviews of this paper. We thank Raúl Gío Argáez and Ana Luisa Carreño for facilitating contacts with Yolanda Hornelas from the Scanning Electron Microscopy Laboratory of the Marine and Limnological Sciences Institute, National Autonomous University of Mexico who prepared the SEM images. Brenda Martinez from the Laboratory of Micropaleontology, National Autonomous University of Mexico prepared the samples for SEM and light microscopy photography. GC acknowledges the National Agency for the Promotion of Science and Technology (ANPCyT), PICT 2010-0082, CONICET Projects PIP 00819 and 00021, and the Comahue National University (Project
B166) for support of this research. MM acknowledges financial support for the collection of the samples from NSF (EAR-0542993), ACS/PRF (45910-AC8), and assistance from A. Cohen, J. Omarini, C. Gans, A. Kirschbaum, L. Lupo, R.G. Cortes and the staff at Monumento Natural Laguna de los Pozuelos.

\section{Scientific editing by Alan Lord}

\section{References}

Bertels, A. \& Martinez, D. 1990. Quaternary ostracodes of continental and transitional littoral-shallow marine environments. Courier Forschungsinstitut Senckenberg, 123, 141-160.

Bonaventura, S.M., Tecchi, R. \& Vignale, D. 1995. The vegetation of the Puna Belt at laguna de Pozuelos Biosphere Reserve in northwest Argentina. Plant Ecology, 119, 23-31.

Calderoni, G., Carrara, C. et al. 1994. Palaeoenvironmenal, palaeoclimatic and chronological interpretations of late Quaternary sediment core from Pliana di Rieti (Central Apennines, Italy). Giornale di Geologia, ser, 3, 56, 43-72.

Cladouhos, T.T., Allmendinger, R.W., Coira, B. \& Farrar, E. 1994. Late Cenozoic deformation in the Central Andes: Fault kinematics from the northern Puna, northwestern Argentina and southwestern Bolivia. Journal of South American Earth Sciences, 7, 209-228.

Cohen, A.S., McGlue, M.M., Ellis, G.S., Swarzenski, P.W., Zani, H., Assine, M.L. \& Silva, A. 2014. Lake formation, characteristics and evolution in retroarc deposystems: a synthesis of the modern Andean orogen and its associated basins. In: DeCelles, P.G., Ducea, M.N., Carrapa, B. \& Kapp, P.A. (eds) Geodynamics of a Cordilleran Orogenic System: The Central Andes of Argentina and Northern Chile. Geological Society of America Memoirs, 212, 309-335, http://doi.org/10.1130/2015.1212(16)

Cusminsky, G.C. \& Whatley, R.C. 1996. Quaternary non-marine ostracods from lake beds in northern Patagonia. Revista Española de Paleontología, 11, 143-154.

Cusminsky, G.C., Pérez, P.A., Schwalb, A. \& Whatley, R. 2005. Recent lacustrine ostracods from Patagonia, Argentina. Revista Española de Micropaleontología, 37, 431-450.

Daday, E.V. 1902. Mikroskopische-süsswasserthiere aus Patagonien. Természetrajzi Füzetek, 25, 201-313.

D'Ambrosio, D.S., Diaz, A.R., Garcia, A. \& Claps, M.C. 2015. First description of the soft part anatomy of Ilyocypris ramirezi Cusminsky \& Whatley (Crustacea, Ostracoda) from Argentina, South America. Zootaxa, 3957, 59-68.

De Deckker, P. 1981. On Eucypris fontana (Graf). Stereo-Atlas of Ostracod Shells, 8, 87-92.

Delorme, L.D. 1971. Freshwater ostracodes of Canada, Part 5: Families Limnocytheridae, Loxoconchidae. Canadian Journal of Zoology, 49, 43-64.

Diebel, K. \& Pietrzeniuk, E. 1975. Ostracoden aus dem holozänen Travertin von Bad Lagensalza. Quartärpaläontologie, 1, 27-55.

Forester, R.M. 1988. Nonmarine calcareous microfossils sample preparation and data acquisition procedures. US Geological Survey Technical Procedure, HP-78 R1, 1-9.

García, A. 1994. Charophyta: Their use in paleolimnology. Journal of Paleolimnology, 10, 43-52.

Garreaud, R.D., Vuille, M., Compagnucci, R. \& Marengo, J. 2009. Presentday South American climate. Palaeogeography, Palaeoclimatology, Palaeoecology, 281, 180-195.

Gutentag, E.D. \& Benson, R.H. 1962. Neogene (Plio-Pleistocene) fresh-water ostracodes from the Central High Plains. Kansas Geological Survey Bulletin, 157, 1-60.

Igarzábal, A.P. 1978. La Laguna de Pozuelos y su Ambiente Salino. Acta Geologica Lilloana, 15, 80-103.

Legates, D.R. \& Willmott, C.J. 1990a. Mean seasonal and spatial variability in gauge-corrected, global precipitation. International Journal of Climatology, 10, 111-127.

Legates, D.R. \& Willmott, C.J. 1990b. Mean seasonal and spatial variability in global surface air temperature. Theoretical Applied Climatology, 41, 11-21.

Lerner-Seggev, R. 1973. Limnocythere titicaca new species (Ostracoda, Cytheridae) from Lake Titicaca, Bolivia. Crustaceana, 25, 88-94.

Martens, K. \& Behen, F. 1994. A checklist of the Recent non-marine ostracods (Crustacea, Ostracoda) from the inland waters of South America and adjacent islands. Travails Scientifique du Musée National d' Histoire Naturalle Luxembourg, 22, 1-88.

Martens, K. \& Savatenalinton, S. 2011. A subjective checklist of the Recent, free-living, non-marine Ostracoda (Crustacea). Zootaxa, 2855, 1-79.

McGlue, M.M., Ellis, G.S., Cohen, A.S. \& Swarzenski, P.W. 2012. Playalake sedimentation and organic matter accumulation in an Andean piggyback basin: The recent record from the Cuenca de Pozuelos, North-west Argentina. Sedimentology, 59, 1237-1256.

McGlue, M.M., Cohen, A.S., Ellis, G.S. \& Kowler, A.L. 2013. Late Quaternary stratigraphy, sedimentology and geochemistry of an underfilled lake basin in the Puna plateau (northwest Argentina). Basin Research, 25, 1-21.

Mirande, V. \& Tracanna, B.C. 2009. Estructura y controles abioticos del fitoplancton en humedales de altura. Ecología Austral, 19, 119-128. 
Mourguiart, P. \& Corrège, T. 1998. Écologie et paléoécologie des ostracodes actuels et Holocènes de l'Altiplano Bolivien. Bulletin du Centre de Recherches Elf Exploration et Production, Mémoire, 20, 103-115.

Palacios-Fest, M.R. 1994. Nonmarine ostracode shell chemistry from Hohokam irrigation canals in Central Arizona: A paleohydrochemical tool for the interpretation of prehistoric human occupation in the North American Southwest. Geoarchaeology, 9, 1-29.

Purper, I. \& Pinto, I.D. 1980. Interglacial ostracodes from Wasa Mayu, Bolivia. Pesquisas, Porto Alegre, 13, 161-184

Ramirez, R.C. 1967. Ostrácodos de lagunas de la provincia de Buenos Aires. Revista del Museo de La Plata (ns), Sección Zoología, 10, 5-54.

Romanov, R.E. \& Barinova, S.S. 2012. The charophytes of Israel: Historical and contemporary species richness, distribution, and ecology. Biodiversity Research and Conservation, 25, 67-74.

Schwalb, A., Burns, S.J., Cusminsky, G., Kelts, K. \& Margraf, V. 2002. Assemblage diversity and isotopic signals of modern ostracodes and host waters from Patagonia, Argentina. Palaeogeography, Palaeoclimatology, Palaecology, 187, 323-339.

Tressler, W.L. 1949. Freshwater Ostracoda from Brazil. Proceedings of the United States National Museum, Smithsonian Institution, 100, 61-83.
Tunoglu, C., Ternel, A. \& Gençonglu, H. 1995. Pliocene Ostracoda association and environmental characteristics of Sivrihisar (Eskisehir) area, Central Anatolia, Turkey. In: Riha, J. (ed.) Ostracoda \& Biostratigraphy. Balkema, Rotterdam, 265-275.

Whatley, R.C. \& Cholich, T.C. 1974. A new Quaternary ostracod genus from Argentina. Palaeontology, 17, 669-684.

Wood, R.D. 1959. Gametangial constants of extant Charophyta for use in micropaleobotany. Journal of Paleontology, 33, 186-194.

Wood, R.D. 1967. Charophytes of North America: A guide to the species of Charophyta of North America, Central America, and the West Indies. Monograph of the Characeae. University of Rhode Island, Kingston.

Zabert, L.L. 1981. Ostrácodos cuaternarios de Taco Pozo (provincia de Chaco, Argentina) con algunas consideraciones paleoecológicas. Facena, 4, 77-87.

Zhencheng, S., Feng, X., Li, D., Yung, F., Qu, Y. \& Wang, H. 1999. Cenozoic Ostracoda and palaeoenvironments of the northeastern Tarim Basin, western China. Palaeogeography, Palaeoclimatology, Palaeoecology, 148, 37-80.

Zhou, J. \& Lau, K.M. 1998. Does a monsoon climate exist over South America? Journal of Climatology, 11, 1020-1040.

Zviedre, E. 2007. Genus Chara L. in Latvia - Freshwater species and their identification. Acta Biologica Universitatis Daugavpiliensis, 7, 139-147. 